\title{
ESL Learners' Obstacles in Learning Speaking Skills
}

\author{
Rose Suzila Yahaya \\ Universiti Kuala Lumpur, \\ Royal College of Medicine Perak (UniKL RCMP), Malaysia. \\ Noor Alhusna Madzlan \\ Faculty of Languages and Communication, \\ Universiti Pendidikan Sultan Idris (UPSI), Malaysia. \\ Mazura@Mastura Muhammad \\ Faculty of Languages and Communication, \\ Universiti Pendidikan Sultan Idris (UPSI), Malaysia.
}

\begin{abstract}
English is regarded as a second language in Malaysia and is part of the compulsory learning subject in primary and secondary school. However, the learning span of six years in primary school and five years in secondary school does not assure that the students will be able to master their speaking skills. Many of our students are still struggling to speak in English with correct sentence structures and pronunciations. Therefore, this paper aims to discuss the obstacles faced by ESL learners in their speaking skills. Learning perception, anxiety, and social-related problems as well as learningrelated problems, were the focus of issues discussed in this paper. This study engaged a quantitative approach to collect the data. The online survey, through "Google Form" was used to obtain data from the 196 tertiary level ESL respondents at one of the higher learning institutions in Ipoh. An adapted questionnaire was used for this study. The questionnaire was constructed in the form of a 5-point Likert Scale from which the choices range from strongly agree to strongly disagree. The items on the questionnaire were analyzed using SPSS 26 and the mean score for each item constructed was calculated accordingly. Findings indicated that the respondents experienced interference of L1 when it comes to difficulty in speaking. The respondents also expected the teacher to correct every error that they say and want the teacher to use a variety of methods and latest approaches to teach speaking skills to boost their interest. This study suggests that ESL learners need to be given more motivation to develop their confidence in using the English language and teachers need to be more creative in implementing strategies that stimulate learners' interest to speak in English.
\end{abstract}




\section{KEYWORDS: ESL learners, obstacles, speaking skills Introduction}

Accuracy of speaking correct grammar, pronunciation, and vocabulary is always emphasized, therefore fluency is difficult for the students to grasp especially the ESL learners. The flow of the speaker expressing his or her ideas in speaking with the correct pronunciation and tone without much hesitation and unnecessary pause is associated with fluency (British Council, 2021) . In contrast, accuracy points to the ability of the speaker to use appropriate vocabulary, grammar and punctuation correctly (British Council, 2021).

This aligned with the previous studies carried out by Bailey (2003) and Byrne (1986) which indicated that to be considered fluent, one should be able to use the target language smoothly and assertively without too much pausing that could initiate interruptions in his / her communication. This was further supported by Shahini and Shahamirian (2017) stating that fluency is one of the major traits in speaking competency. Meanwhile, Kaushik (2017) was of the opinion that in language learning, fluency and accuracy are equally important for conveying and expressing the speaker's ideas effectively. In Malaysia, Malaysian students were not at par in their English speaking fluency especially outside their classroom setting even though they learned the language for 11 years. Hence, the researchers would like to explore the challenges that ESL learners face in their English speaking skills.

\section{Background of the study}

This study aimed to understand the obstacles that obstructed the ESL learners' learning speaking skills at one of the private universities in Malaysia. The learners were the Health Sciences students of diploma and degree levels from various programs namely Pharmacy, Nursing, MBBS, Physiotherapy, and Pharma Technology. Some of them, especially nursing, had been exposed to the clinical environment in the government hospital where $90 \%$ of their clinical exposures were in Bahasa Malaysia. Learners were in mixed groups in terms of proficiency in English. The formal lessons that the learners obtained in primary and secondary schools for 11 years were unable to ensure their capability to speak English fluently and accurately. Taking into consideration that the learners came from various backgrounds, social levels, and different proficiency levels, it was important to understand how the learners perceive speaking skills from their perspective.

\section{Methodology}

This study engaged a purposive sampling technique to select the respondents. This technique was engaged by the researchers as it gave freedom to choose the right respondents based on the judgment of the researcher. Furthermore, this technique was suitable for the quantitative approach as used in this study. Through the purposive sampling technique, researchers were able to pre-set specific criteria that the respondents had undergone at least 11 years of learning ESL during their high school to ensure the selected respondents answered the research questions accurately. Based on this criteria, 196 ESL respondents of the tertiary level at one of the higher learning institutions 
in Ipoh were selected. Aligned with this, the online survey, through "Google Form" was used to obtain data from the respondents. An adapted questionnaire, Moulida (2019), Afshar and Asakereh (2013) were used for this study respectively.

The questionnaire consisted of 30 items with 28 negative constructs and 2 positive constructs. There were various schools of thought regarding these negative and positive constructs. There were opinions stating that negative constructs will mislead the respondents and ruin the data. However, the researchers believed by including both negative and positive constructs, the respondents were exposed to the facts and data that the researchers want to obtain from them. The researchers' stance was supported by the study done by Kamoen (2012) that reported respondents responded better when the question was worded negatively. The items were further segregated into 3 parts, namely, learners' perception of speaking skills, anxiety, and social-related problems, and learning-related problems. It was constructed in the form of a 5-point Likert Scale from which the choices range from strongly agree to strongly disagree. The items on the questionnaire were analyzed using SPSS 26 and the mean score for each item constructed was calculated accordingly.

Table 1: Reliability Values for Variables

\begin{tabular}{|l|c|c|}
\hline & \multicolumn{2}{|c|}{ Reliability Statistics } \\
\hline Variable & Cronbach's Alpha & N of Items \\
\hline Learner Perception &, 701 & 34 \\
\hline Learning Related Problem &. .811 & 34 \\
\hline $\begin{array}{l}\text { Anxiety and Social Related } \\
\text { Problems }\end{array}$ & .858 & 34 \\
\hline All Variables & .915 & 34 \\
\hline
\end{tabular}

As shown in Table 1, a pilot study was conducted to ensure the reliability of the questionnaire. The score of the Cronbach's Alpha for all the variables was 0.915, which indicated that the questionnaire possessed an acceptable internal consistency $(\mathrm{a}=0.915)$. This was supported by Cortina (1993), whereby the score above 0.70 is acceptable, but 0.80 or greater is preferred, therefore, the questions in the questionnaire were considered as reliable.

\section{Findings and discussion}

The findings of the first research question, which was on the perception of ESL learners in learning speaking skills is summarized in Table 2 below.

Table 2: Learning Perception (LP)

\begin{tabular}{|l|c|c|c|c|c|}
\hline & N & Min. & Max. & Mean & $\begin{array}{c}\text { Std. } \\
\text { Deviation }\end{array}$ \\
\hline $\begin{array}{l}\text { I am very interested in speaking English } \\
\text { learning }\end{array}$ & 196 & 1 & 4 & 3.36 & .645 \\
\hline $\begin{array}{l}\text { Speaking English is very important } \\
\text { especially as a front liner in my field }\end{array}$ & 196 & 1 & 4 & 3.55 & .602 \\
\hline $\begin{array}{l}\text { I always regard speaking as a difficult task } \\
\text { to perform }\end{array}$ & 196 & 1 & 4 & 2.54 & .861 \\
\hline
\end{tabular}




\begin{tabular}{|l|l|l|l|l|l|}
\hline $\begin{array}{l}\text { I hardly relate and applied my speaking } \\
\text { lessons to my daily life }\end{array}$ & 196 & 1 & 4 & 2.49 & .826 \\
\hline
\end{tabular}

Table 2 shows the mean score of respondents' learning perception ranges between 3.55 (the highest) to 2.49 (the lowest). The respondents agreed that speaking English was very important in their career and they were interested in learning the skills $(m=3.55)$. However, the respondents seemed to consider speaking as an uncomfortable task to perform as they were not able to relate and apply the speaking knowledge that they have learned to their daily life $(\mathrm{m}=2.49)$ especially during their clinical attachment as doctors, nurses, and pharmacists were using a lot of medical terms. As a solution to this, speaking lessons in the ESL classroom should be authentic as this will make the learners feel comfortable and able to relate it to their daily life usage. Apart from that, teaching ESP for these groups of Health Sciences learners is another option that should be considered. Table 3 and Table 4, respectively, show the findings for the second research objective, which was to identify the obstacles faced by the ESL learners in learning speaking skills.

Table 3: Anxiety and Social Related Problem (ASRP)

\begin{tabular}{|l|c|c|c|c|c|}
\hline & $\mathrm{N}$ & Min. & Max. & Mean & $\begin{array}{c}\text { Std. } \\
\text { Deviation }\end{array}$ \\
\hline $\begin{array}{l}\text { I always feel anxious when I speak English in a } \\
\text { public especially in front of strangers }\end{array}$ & 196 & 1 & 4 & 2.89 & .891 \\
\hline I am afraid of making mistakes & 196 & 1 & 4 & 3.01 & .894 \\
\hline $\begin{array}{l}\text { I do not have good command of English } \\
\text { speaking skills }\end{array}$ & 196 & 1 & 4 & 2.74 & .869 \\
\hline I feel afraid of being center of attention & 196 & 1 & 4 & 2.89 & .846 \\
\hline I have no motivation in speaking English & 196 & 1 & 4 & 2.23 & .873 \\
\hline Shyness prevents me from speaking English & 196 & 1 & 4 & 2.64 & .964 \\
\hline $\begin{array}{l}\text { Some of my course mates speak English very } \\
\text { fluently, unlike me, and this demotivates me. }\end{array}$ & 196 & 1 & 4 & 2.57 & 1.003 \\
\hline I only speak English during English class & 196 & 1 & 4 & 2.40 & .856 \\
\hline $\begin{array}{l}\text { I have difficulty finding opportunities to } \\
\text { practice my speaking outside the classroom }\end{array}$ & 196 & 1 & 4 & 2.43 & .923 \\
\hline $\begin{array}{l}\text { I do not think I will make use of English } \\
\text { speaking skills in my career as I'm going to } \\
\text { work in the government hospital }\end{array}$ & 196 & 1 & 4 & 1.96 & .828 \\
\hline
\end{tabular}

Table 3 focuses on the obstacles related to Anxiety and Social Related Problems. Findings revealed that the respondents were afraid of making mistakes during the speaking process, $(\mathrm{m}=3.01)$. This finding is similar to the study performed by Al Nakhalah (2016), that indicated the reasons for speaking difficulties among English language students at Al Quds Open University included fear of making mistakes, shyness, anxiety, and lack of confidence. Making mistakes made the respondents feel that they were the center of attention $(\mathrm{m}=2.89)$, and alternatively made them reluctant to speak in English, especially in front of strangers $(\mathrm{m}=2.89)$.

Other obstacles faced by ESL learners were the lack of good command in English speaking skills. As mentioned in the study conducted by Zhengdong (2011), ESL students faced a stumbling block 
in their spoken English as they had to respond immediately to the conversation and had little space to think much of what they were going to say. This was further supported by Krashen's (1988) argument that when second language speakers rely on "feel" for correctness without prior planning, they will make grammatical errors. This finding suggests that some ESL learners were unable to respond spontaneously to speaking conversation as they needed time to construct the sentence before responding accordingly.

Table 4 illustrated the obstacles of learning speaking skills in learning related problems.

Table 4: Learning Related Problem

\begin{tabular}{|c|c|c|c|c|c|}
\hline & $\mathbf{N}$ & Min. & Max. & Mean & $\begin{array}{l}\text { Std. } \\
\text { Deviation }\end{array}$ \\
\hline I want to learn speaking skills well very much & 196 & 1 & 4 & 3.59 & .622 \\
\hline $\begin{array}{l}\text { Choosing proper vocabulary in speaking is very } \\
\text { difficult }\end{array}$ & 196 & 1 & 4 & 2.88 & .842 \\
\hline $\begin{array}{l}\text { I want the teacher to correct every error that I } \\
\text { say }\end{array}$ & 196 & 1 & 4 & 3.32 & .712 \\
\hline $\begin{array}{l}\text { My mother tongue always interferes with my } \\
\text { speaking English learning }\end{array}$ & 196 & 1 & 4 & 2.46 & .867 \\
\hline $\begin{array}{l}\text { When I come to difficult sentences in speaking, } \\
\text { I always think in Malay first and translate them } \\
\text { into English }\end{array}$ & 196 & 1 & 4 & 3.01 & .832 \\
\hline $\begin{array}{l}\text { I cannot choose the proper words in expressing } \\
\text { meaning in speaking English }\end{array}$ & 196 & 1 & 4 & 2.72 & .845 \\
\hline $\begin{array}{l}\text { I always make the same mistakes in choosing } \\
\text { words in oral form and cannot correct them } \\
\text { easily. }\end{array}$ & 196 & 1 & 4 & 2.64 & .821 \\
\hline $\begin{array}{l}\text { My teachers' teaching methods do not } \\
\text { encourage students to speak. }\end{array}$ & 196 & 1 & 4 & 1.83 & .823 \\
\hline $\begin{array}{l}\text { I am afraid that other students will laugh at me } \\
\text { because of my pronunciation. }\end{array}$ & 196 & 1 & 4 & 2.66 & .966 \\
\hline $\begin{array}{l}\text { My teachers' teaching was too text book } \\
\text { oriented. }\end{array}$ & 196 & 1 & 4 & 2.13 & .837 \\
\hline $\begin{array}{l}\text { There is a lack of autonomy in my speaking } \\
\text { lessons. }\end{array}$ & 196 & 1 & 4 & 2.39 & .818 \\
\hline $\begin{array}{l}\text { My classes are teacher- centered, therefore, I } \\
\text { cannot find the chance to express my ideas and } \\
\text { participate in class discussion activities. }\end{array}$ & 196 & 1 & 4 & 2.17 & .783 \\
\hline $\begin{array}{l}\text { My speaking class is overcrowded, therefore no } \\
\text { personal attention could be given by the } \\
\text { teachers. }\end{array}$ & 196 & 1 & 4 & 2.34 & .859 \\
\hline $\begin{array}{l}\text { The intervention and error correction of my } \\
\text { teacher is too harsh. }\end{array}$ & 196 & 1 & 4 & 1.96 & .793 \\
\hline $\begin{array}{l}\text { My teachers do not encourage any group work } \\
\text { or pair work; this inhibits student - student } \\
\text { interaction in class. }\end{array}$ & 196 & 1 & 4 & 1.84 & .778 \\
\hline
\end{tabular}


ESL Learners' Obstacles in Learning Speaking Skills

\begin{tabular}{|l|c|c|c|c|c|}
\hline $\begin{array}{l}\text { My teachers do not present interesting topics for } \\
\text { discussion. }\end{array}$ & 196 & 1 & 4 & 1.91 & .827 \\
\hline I do not have enough vocabulary knowledge. & 196 & 1 & 4 & 2.52 & .807 \\
\hline $\begin{array}{l}\text { My speaking teachers spend a large proportion } \\
\text { of class time asking questions about things to } \\
\text { which they already knew the answers; therefore, } \\
\text { no real communication takes place. }\end{array}$ & 196 & 1 & 4 & 2.27 & .765 \\
\hline I am afraid of grammatical errors. & 196 & 1 & 4 & 2.95 & .846 \\
\hline $\begin{array}{l}\text { Teachers should use a variety of methods and } \\
\text { latest approaches to teach speaking skills to } \\
\text { boost students' interest. }\end{array}$ & 196 & 1 & 4 & 3.29 & .725 \\
\hline Valid N (list wise) & 196 & & & & \\
\hline
\end{tabular}

From Table 4, the respondents had the willingness to learn speaking skills well. However, it seems that they were too dependent on their teachers as they wanted the teachers to correct every error that they made. From findings by Horwitz, Horwitz \& Cope (1986), Truscott (1996), Young (1991) and Walker (1973), error correction had negative effects as some students preferred not to be corrected for each speaking and writing error. This practice undermined their confidence and forced them to take so much effort on details that they lost the overall ability to use language. Excessive feedback can prevent learning to take place because if everything is being corrected, learners become too dependent on their teacher, it reduces self-confidence and ultimately, they would tend to avoid saying anything unless they are sure it was correct. It is suggested that teachers can identify students that preferred close guidance in their speaking skills instead of generalizing the finding that all students wanted to be corrected for every error that they made. Rewarding students that manage to speak English for the whole day in class, on one chosen day per week, could motivate them to speak without worrying about the correctness of each of their sentences.

Similarly, the interference of their L1 was another obstacle faced by the respondents when it comes to difficult sentences in speaking. They typically think of a particular sentence in Malay first, and then translate it into English. According to the study by Ye (2013), English learners in China had similar problems. These included the interference of L1 in their speech in the classroom, and too much emphasis was given to memorizing grammatical rules and vocabulary.

Finally, in terms of learning speaking skills, the respondents wanted the teachers to use a variety of methods as well as the latest approaches in teaching to boost the students' interest. Prabhu (1990), however, stated that there was no better method in teaching languages. Different methods were best for different teaching contexts and groups of learners. Teachers can use a variety of approaches to engage the students in the lesson accordingly.

\section{Conclusion and Recommendation}

Based on the findings, it was indicated that the learners were fully aware that the ability to speak in English was crucial and they were immersed to learn the language. However, most ESL learners regard speaking as a tough task to perform. On top of that, they claimed that the speaking lessons they learned in ESL classes were not able to be adapted in their daily life. 
Findings from the questionnaire stated that the obstacles to speaking English among ESL learners were based on two major factors; anxiety and social-related problems, and learning-related problems. Anxiety and social-related problems were the obstacles that were due to the learner's inner-self such as confidence, motivation, and self-esteem. In this study, most of the ESL learners were afraid to make mistakes as they wished that they could speak like a native speaker. In comparison, the study by Shen \& Chue, (2019) and Zhang (2009) stated that speaking English created a challenge for most EFL learners too as the common difficulties included worries about making mistakes, fears for criticism, and shyness. Therefore, as ESL learners, these obstacles should not be the reasons not to learn speaking skills as EFL learners also have the same problems.

On the other hand, learning-related problems include aspects such as grammar, pronunciation, vocabulary, teacher teaching method/approach, and learners' expectations. Based on the responses from the questionnaire, learners were enthusiastic to learn speaking skills. However, the ESL learners were too dependent on their teachers' guidance. They wanted the teacher to correct every error that they have made. Bartran and Walton (1994) were of the opinion that in learning speaking skills, teachers should only correct those errors that obstruct the communication; while areas related to grammar structure, function, or skill should be corrected separately. Too many error corrections will demotivate the learners and lead to a lack of self-confidence to speak English. Teachers should lead the learners to accept the errors as part of the learning process that will make them better speakers.

Subsequently, the learners wanted a variety of methods and the latest approaches to be used to teach speaking skills by the teachers. As mentioned by Prabhu (1990), there was no better method in teaching languages. Similarly, Roa (2019), stated that EFL and ESL teachers should employ different approaches and techniques of teaching speaking skills such as Padlet, Vlog and many others to enhance the learners' interest. The new generation of Gen Z (the newest generation between 1997 and 2012) and Gen A (Alpha generation born in 2012) are the generations that are highly attached to gadgets, social media, hip-hop, and rap music. All these elements should be used to get their engagement in more interesting speaking skills activities.

Another obstacle that was highlighted in the questionnaire was the interference of L1 where the learners always think in Malay first and translate them into English. Studies done by Premela and Oh (2020) on Chinese L2 students stated that the interferences were due to lack of opportunities for practice and the struggle for proper vocabulary. The researchers further suggest that it was important to have a good fundamental knowledge of linguistics as it could reduce conflict and misinterpretation of meaning in speaking. For instance, wrong pronunciation might lead to a different meaning which further creates misunderstanding to the other party that is unfamiliar with the slang. This was supported by Krashen's (1981) findings that the interference of L1 on L2 signaled poor fundamentals, but it can be reduced with speaking practice. 


\section{Recommendation}

Since the present study focused on one particular institute, the results should not be generalized to all ESL speaking learners. The following suggestions are proposed to obtain better results. The first suggestion is to involve other campuses of the university in this study as this could generate more reliable results. The second recommendation is to compare speaking obstacles among other ESL learners specific to the different programmes offered at tertiary level rather than studying ESL learners in general, as each programme might face different obstacles. As such, adopting ESP to this particular group of learners is another option that should be considered.

\section{References}

Afshar, S. H. \& Asakereh, A. (2016). Speaking skills problems encountered by Iranian EFL freshmen and seniors from their own and their English instructors' perspectives. Electronic Journal of Foreign Language Teaching, 13(1), 112-130.

Al Nakhalah, A. M. M. (2016). Problems and difficulties of speaking that encounter English language students at Al Quds Open University. International Journal of Humanities and Social Science Invention, 5(12), 96-101.

Bailey, K. M. (2003). Practical English language teaching. New York: McGraw-Hill Contemporary.

Barnard, R. (2002). Peer tutoring in the primary classroom: A sociocultural interpretation of classroom interaction. New Zealand Journal of Educational Studies, 37(1), 57-72.

Bartran, M., \& Walton, R. (1994). Correction: A positive approach to language mistakes. Language Teaching Publications: England.

British Council Foundation Indonesia (2021). Fluency vs Accuracy. Retrieved from https://www.britishcouncilfoundation.id/en/english/articles/fluency-vs-accuracy

Byrne, D. (1986). Teaching Oral English. Cambridge: Cambridge University Press.

Cortina, J. M. (1993). What is coefficient alpha? An examination of theory and applications. Journal of Applied Psychology, 78(1), 98-104

Horwitz, E.K. M.B. Horwitz \& J. Cope. (1986). Foreign language classroom anxiety. The Modern Language Journal, 70(2), 125-132.

Kamoen, N. (2012). Positive versus negative: A cognitive perspective on wording effects for contrastive questions for attitude surveys: A thesis in English Language studies (Doctoral thesis). Tilburg University, Netherlands.

Kaushik, B. (2017). Accuracy or Fluency First...? Pune Research. An International Journal in English, 3(4), 1-9.

Krashen, S. D. (1981). Second language acquisition and second language learning. University of Southern California: Pergamon Press Inc. 
Krish, P. \& Oh, C.M. (2020). A case study of L1 interference in speech acts among Chinese L2 students. The Southeast Asian Journal of English Language Studies, 26(1), 106 - 118.

Moulida, I. (2019). Students' challenges in English public speaking at Dayah Darul Ihsan. A thesis in English Language Education (Doctoral Dissertation). UIN Ar-Raniry, Banda Aceh, Indonesia.

Palpanadan, S., Salam, A. R., \& Ismail, F. B. (2014). Comparative analysis of process versus product approach of teaching writing in Malaysian schools: Review of literature. MiddleEast Journal of Scientific Research, 22(6), 789-795.

Prabhu, N.S. (1990). There is no best method-Why? TESOL Quarterly, 24(2), 161-176

Roa, P. S. (2019). The importance of speaking skills in English classrooms. Alford Council of International English \& Literature Journal (ACIELJ), 2(2), 6-18.

Shahini, G., \& Shahamirian, F. (2017). Improving English speaking fluency: The role of six factors. Advances in Language and Literary Studies, 8(6), 100-104.

Shen, M. and Chiu, T. (2019), EFL Learners' English speaking difficulties and strategy use. Education and Linguistics Research, 5(2), 88-102.

Truscott, J. (1996). The case against grammar correction in L2 writing Classes. Language Learning, 46 (2), 327-369., 1998.

Walker, J. L. (1973). Opinions of university students about language teaching. Foreign Language Annals 7, 102-05

Ye, R. (2013). Discussion on interference from L1 culture to L2 writing and handling suggestions. International Conference on Education Technology and Management Science ICETMS, 36-38.

Young, D.J. (1991). Creating a low-anxiety classroom environment: What does language anxiety research suggest?. The Modern Language Journal, 75(4), 426-439.

Zhang, S. (2009). The role of input, interaction, and output in the development of oral fluency. English Language Teaching, 2(4), 91-100.

Zhengdong, G. (2011). Understanding L2 speaking problems: Implications for ESL curriculum development in a teacher training institution in Hong Kong. Australian Journal of Teacher Education, 37(1), 43-59. 